\title{
A representação literária de La Malinche no século XX
}

\author{
La Malinche's literary representation in the twentieth century
}

\author{
Dóris Helena Soares da Silva Giacomolli ${ }^{1}$ \\ https://orcid.org/0000-0001-5699-0523 \\ http://lattes.cnpq.br/7121110420173190
}

Enviado em: 30/08/2019

Aceito em: 07/11/2019

\begin{abstract}
RESUMO: Esse artigo tem por objetivo analisar as representações de Malinche na literatura do século XX. La Malinche, batizada pelos espanhóis de Marina, chamada de Doña Marina e também Malinalli, tradutora indígena de Hernán Cortés, teve seu nome quase apagado para que os homens que, se valendo do direito do mais forte, tivessem os seus nomes aclamados como conquistadores, para que alcançassem títulos e fossem relembrados em datas comemorativas. Ela foi nomeada por Hernán Cortés em suas Cartas de relación e, principalmente, por Bernal Díaz em Historia verdadera de la conquista de Nueva España. Conclui-se que os escritores estudados do século XX se pautaram pelas fontes primárias e historiografia para representar sua personagem.
\end{abstract}

Palavras-chave: Malinche. Literatura. História. Representação literária de personagem histórico.

ABSTRACT: This article aims to analyze the representations of Malinche in twentieth century literature. La Malinche, baptized by the Spanish of Marina, called Doña Marina and also Malinalli, an indigenous translator of Hernán Cortés, had her name almost erased so that men who, using the right of the fittest, would have their names hailed as conquerors, to achieve titles and to be remembered on commemorative dates. She was named by Hernán Cortés in his Letters of Relation and, mainly, by Bernal Díaz in True History of the conquest of Nueva España. It is concluded that the studied writers of the twentieth century were based on primary sources and historiography to represent their character.

Keywords: Malinche. Literature. Story. Literary representation of historical character.

\section{Introdução}

A literatura contribui imensamente no processo de construir um outro olhar sobre a História e se torna uma fonte para se pensar relações sociais e culturais, quando colabora para resgatar personagens das margens da historiografia oficial, nomeadamente Malinche.

Não partimos do pressuposto de que os romancistas querem criar uma narrativa que dê conta da "verdadeira" Malinche. A literatura não tem compromisso com o passado, mas com o presente. Ela se insere em uma ordem presentista, na qual a figura de Malinche responde aos anseios e às regras literárias do presente. Dito isso, cabe ainda dizer que a literatura segue de perto as fontes primárias e a historiografia "uma vez que os dois discursos se estruturam da mesma maneira, e da mesma maneira lhes é dado sentido." (GIACOMOLLI, 2014, p. 31). Não há como negar que há "uma estreita relação entre historiografia,

\footnotetext{
${ }^{1}$ Doutoranda em História da Literatura - FURG e doutoranda em Estudos de Literatura e História - UFPEL. Professora estadual no estado do Rio Grande do Sul. E-mail: dorishssg@gmail.com
} 
literatura e textos de ficção, aproximando fatos reais e imaginados." (GIACOMOLLI, 2014, p. 31).

A literatura se baseia estreitamente na História para criar seus personagens, já que a fronteira entre as duas é imprecisa:

A distinção entre história e ficção é imprecisa. A literatura pode apresentar narrativas de ficção como se fossem reais, trazendo personagens verdadeiros para a ficção literária. Há semelhanças entre a narrativa histórica e o relato ficcional uma vez que os dois discursos estruturam-se da mesma maneira e da mesma maneira lhes é dado sentido. (GIACOMOLLI, 2014, p. 30).

As provas que faltam à História, as evidências que foram apagadas, os retalhos que foram perdidos, a vértebra perdida para completar o esqueleto, a imaginação pode preencher nos trabalhos literários. Quando ignoramos os detalhes, completamos; quando não temos certeza, imaginamos. O que foi perdido, as cavidades, os espaços em branco, os orifícios vazios podem ser completados pela fantasia e imaginação daquele que escreve. $\mathrm{O}$ possível, o que poderia ter sido, o razoável, o admissível, o plausível, vem preencher o que poderia, ou pode, ser verdade. A fantasia pode vir a completar os fatos. A literatura completa a História.

Malinche foi presenteada aos espanhóis pelos nativos de Tabasco, em 1519. Essa nativa falava fluentemente os idiomas maia e nahuátl. Logo aprendeu o espanhol. Tornouse tradutora e acompanhou Cortés; ao seu lado, ela viu Hernán Cortés conquistar e dizimar o povo asteca ${ }^{2}$ e sua capital Tenochtitlán. Mais tarde, eles se tornaram amantes e tiveram um filho chamado Martín. Malinche é poucas vezes nomeada pelas fontes primárias.

Hernán Cortés escreveu cinco cartas ao rei Carlos V, e se refere à Malinche na quinta delas, que foi escrita em 1526. Nesta carta, Cortés escreve que sua intérprete se chamava Marina e viajava em sua companhia e que tinha sido dada a ele como presente, entre outras dezenove mulheres.

Respondi que era o capitão de quem o povo de Tabasco falara e que, se ele quisesse saber a verdade, teria apenas de perguntar à intérprete com quem falava, Marina, que viajava sempre na minha companhia depois de ter me sido dada como presente com vinte outras mulheres. (CORTÉS, 1986, p.376, tradução nossa, grifo nosso). ${ }^{3}$

Bernal Díaz (2012) descreveu-a em seu livro The True History of the Conquest of New Spain ${ }^{4}$, como uma mulher de muito boa aparência, inteligente e autoconfiante. Malinche foi descrita, em preciosos detalhes, em um capítulo inteiro do livro de Bernal Díaz, o que não ocorreu em nenhum trabalho de outro historiador da época. Sobre isso, escreve o historiador Maes (2013):

\footnotetext{
${ }^{2}$ The "Aztecs" were the most powerful figures in the political landscape known to the young Malintzin.[...] their ethnic identity was Mexica (me-shee'-ka) (TOWNSEND, 2006, p. 25) Os "astecas" eram as figuras mais poderosas no cenário político conhecido da jovem Malintzin, [...] sua identidade étnica era mexica (me-shee -ka) (TOWNSEND, 2006 , p. 25, tradução nossa)

${ }^{3}$ I replied that I was the captain of whom the people of Tabasco had spoken, and that if he wished to learn the truth he had only to ask the interpreter with whom he was speaking, Marina, who traveled always in my company after she had been given me as a presente with twenty other women. She then told him that what I had said was true and spoke to him of how I had conquered Mexico and of all the other lands which I held subject and had placed beneath Your Majesty's command. (CORTÉS, 1986, p.376).

${ }^{4}$ História Verdadera de La conquista de la Nueva España.
} 
Existem fontes de valor incalculável, como a citada História Verdadeira de Bernal Díaz del Castillo, que contém algumas evidências veementes sobre Malintzin que orientam os escritos históricos sobre a identidade dessa mulher enigmática. (MAES, 2013, p. 34, grifo nosso, tradução nossa). ${ }^{5}$

Além dos escritos históricos, a obra escrita por Bernal Díaz orienta, ainda, muitos trabalhos literários, inclusive esses do nosso corpus literário escolhido neste trabalho, escritos no século XX. Assim ele escreve sobre Malinche:

\begin{abstract}
Aqui está a história dela: seu pai e mãe eram senhores e caciques de uma cidade, Painala, a oito léguas da cidade de Guazacualco, e outras cidades estavam sujeitas a ela. Seu pai morreu quando ela era uma criança muito pequena, e sua mãe se casou com outro jovem cacique com quem teve um filho e, ao que parece, eles o amavam muito, e o pai e a mãe concordaram que ele deveria se tornar cacique após a morte deles. Para evitar obstáculos, uma noite eles deram à criança, dona Marina, alguns índios de Xicalango para que ela não fosse vista. Naquele mesmo tempo, o filho de um de seus escravos indianos morreu e eles anunciaram que quem havia morrido era a herdeira dona Marina. O povo de Xicalango deu doña Marina ao povo de Tabasco e os tabascanos a deram a Cortés. (DEL CASTILLO, 2012, p. 54, tradução nossa). ${ }^{6}$
\end{abstract}

Bernal Díaz escreve que, durante uma viagem a Honduras, ela se casa com um dos soldados de Cortés. "Durante essa jornada, um senhor chamado Juan Jaramillo casou-se com ela na cidade de Orizaba, diante de certas testemunhas." (DEL CASTILLO, 2012, p. 55 tradução nossa). ${ }^{7}$ Bernal Díaz conta como Malinche ficou sabendo de uma armadilha que estava sendo preparada contra os espanhóis: "Ela viu que Dona Marina era jovem, bonita e rica, por isso falou com ela e aconselhou-a a acompanhá-la a sua casa, se quisesse escapar com vida, porque era certo naquela noite ou na próxima. dia eles iam matar todos nós. "(DEL CASTILLO, 2012, p. 168). ${ }^{8}$ Maliche foi contar a Cortés e houve um grande massacre comandado pelos espanhóis contra o povo de Cholula. Graças a isso, também, Malinche passou a ser chamada de traidora. Um dos primeiros a referir-se a ela dessa maneira foi Octávio Paz (1947): "O símbolo da entrega é dona Malinche, a amante de Cortés. É verdade que ela se entrega voluntariamente ao Conquistador, mas este, por pouco deixa de ser útil, esquece. Dona Marina se tornou uma figura que representa as índias, fascinadas, violadas ou seduzidas pelos espanhóis.” (PAZ, 1947, p. 35, tradução nossa). ${ }^{9}$

Malinche quase não era mencionada, quando seu nome ficou conhecido, durante mudanças das perspectivas sociais e políticas, acontecidas na Revolução Mexicana:

\footnotetext{
${ }^{5}$ Sin embargo, existen fuentes de un valor incalculable como la ya mencionada Historia Verdadera de Bernal Díaz del Castillo que contienen algunos indicios vehementes sobre Malintzin y orientan ya a los históricos acerca de la identidad de esta mujer enigmática.(MAES, 2013, p. 34).

${ }^{6}$ Here is her story: Her father and mother were lords and caciques of a town, Painala, eight leagues from the town of Guazacualco, and other towns were subject to it. Her father died when she was a very small child, and her mother married another young cacique with whom she had a son and, it seemed, they loved him very much, and the father and mother agreed that he should become cacique after their deaths. To avoid any obstacles, one night they gave the child, doña Marina, to some Indians from Xicalango so she would not be seen. At that same time, the child of one of their Indian slaves died, and they announced that the one who had died was the heiress doña Marina. The people of Xicalango gave doña Marina to the people of Tabasco, and the Tabascans gave her to Cortés. (DEL CASTILLO, 2012, p. 54).

7 "During that journey a gentleman named Juan Jaramillo married her in the town of Orizaba, before certain witnesses." (DEL CASTILLO, 2012, p. 55).

8 "She had seen that doña Marina was young, good-looking, and rich, so she spoke to her and counseled her to come with her to her house if she wanted to escape with her life, because it was certain that night or the next day they were going to kill all of us." (DEL CASTILLO, 2012, p. 168).

9 "El símbolo de la entrega es doña Malinche, la amante de Cortés. Es verdad que ella se da voluntariamente al Conquistador, pero éste, apenas deja de serle útil, la olvida. Doña Marina se ha convertido en una figura que representa a las indias, fascinadas, violadas o seducidas por los españoles.” (PAZ, 1947, p. 35).
} 
Numa visão nacionalista, se La Malinche gerou o primeiro mexicano, também gerou a traição à raça, à nação, o "malinchismo" para os mexicanos, que criaram tal termo pejorativo como patrulha contra os que se encantam ou se deixam seduzir pelo estrangeiro. (MONTANDON, 2007, p. 20).

Hoje, o termo "Malinchismo" se refere àquelas pessoas que se passam para o lado dos estrangeiros em detrimento de sua própria gente, é um sinônimo de traição, usado pejorativamente.

\section{O Deus da Chuva Chora Sôbre o México, de Laszlo Passuth (1963)}

Em O Deus da Chuva Chora Sobre o México, originalmente escrito e publicado em Húngaro, Laszlo Passuth (1963) imagina soluções fictícias para a história, faz Malinche, sua personagem protagonista, assumir a forma de dominadora depois de ter sido uma moça suave e gentil que só tinha olhos para o "novo senhor de pele branca, o amante único para quem a conduziam todo o ímpeto de seu corpo e sua alma.” (PASSUTH, 1963, p. 122).

Malinche nasce nomeada como Malinalli, em Painala, filha do chefe da cidade, portanto nobre, seria sacrificada a um deus em Tenochtitlán. Seu pai decide que deveria ser anunciada sua morte, que seu corpo seria trocado pelo de uma escrava morta e, para protegê-la de uma morte nos altares, é levada para Tabasco para que partisse com mercadores. É oferecida a um Hernán Cortés embaraçado, juntamente com outras vinte indígenas, que não queria receber o presente, já os rebeldes poderiam ser marcados a ferro em brasa e comprados e vendidos, mas os demais indígenas eram livres. Para que não fossem oferecidas aos deuses em sacrifício, aceitou recebê-las e convertê-las em cristãs. Malinalli foi batizada com o nome de Marina e converteu-se em tradutora por falar a língua nahuátl. Logo, aprende a língua espanhola. Desde o princípio, fala por sua própria conta e afirma aos indígenas que os espanhóis eram poderosos e que todos viveriam em paz, desde que se submetessem a eles, entregassem suas riquezas e seguissem suas ordens.

Passath (1963) representa os presságios ${ }^{10}$, de que nos falou Sahagún (2009, p. 36) que precederam a chegada dos espanhóis e que prenunciavam uma grande desgraça que se abateria sobre os astecas. Um deles falava de uma mulher que ressuscitava, descrita na sexta profecia de Sahagún. Os desenhistas que Montezuma mandou para que retratassem Cortés também é descrito em Passath (1963, p. 109).

Em O Deus da Chuva Chora Sobre o México, dedica-se, principalmente a criar o amor entre Hernán Cortés e Malinche e descrever seu inimigo, Montezuma. Laszlo Passuth (1963) escolhe representar que Malinche e Cortés logo se sentiram atraídos um pelo outro e passaram a ter relações sexuais. Um dos mensageiros de Montezuma, que no romance é chamado de Senhor Furioso, assim descreve a ele, um encontro de Cortés com Malinche: "Figurai-vos o estrangeiro de cabelos de ouro deitado entre as árvores em companhia da escrava. E seus rostos já exprimiam o amor mais intenso. A lua brilhava em suas cabeleiras, e era como se o ouro e a prata se misturassem." (PASSUTH, 1963, p. 115). Malinche é

\footnotetext{
10 1- una llama de fuego muy grande y muy resplandeciento; 2- capitel de un cu de Uitzilopuchtli, que se llamaba Tlacatecca, se encendió milagrosamente y se quemó; 3-cayó un rayo sobre cu de Xiuhtecutli, Dios del fuego, cual estaba techado con paja; 4- de día, haciendo Sol, cayó uma cometa; 5-se levantó la mar de México com grandes olas; 6- se oía en aire de noche una voz de mujerque decía: «jOh, hijos míos, ya nos perdemos!». Algunas veces decía: «¡Oh,hijos míos! ¿Dónde os llevaré?» 7- los cacadores de las aves del agua cacaron una ave parda del tamaño de una grulla, y luego la fueron a mostrar a Moctezuma, [...]y la segunda vez que miró en espejo que tenía ave, de ahí a um poco vio muchedumbre de gente junta que venían todos armados encima de caballos. 8-aparecieron muchas veces mostruos em cuerpos mostruosos. Llevábanlos a Moctezuma, y en viéndolos él en su aposento que se llamaba Tlillancalmécac, luego desaparecían. (SAHAGUN, 2009, pp. 401- 403).
} 
representada intervindo na comunicação entre os povos, não somete servindo de tradutora, mas como sujeito da ação, contando segredos tais como o retorno do deus Quetzacoált, esperado pelos astecas. A probabilidade dessa "comunicação extra" de Malinche, trabalho além de seu ofício de tradutora, contribuiu enormemente para lhe dar o apelido de traidora, O certo é que La Malinche tem sido objeto de interesse de muitos estudiosos ${ }^{11}$ que insistem em estudá-la.

E várias de suas descrições Cita Tabasco, onde Malinalli é doada aos espanhóis. E aqui ele se atém às fontes primárias.

\section{Malinche, de Jane Lewis Brandt Malinche (1981)}

Jane Lewis Brandt (1981) escreve Malinche sob o enfoque de um narrador soldado, apaixonado por Malinche. Arturo Mandragón, personagem, fictício, narra em primeira pessoa, embarca na frota de Hernán Cortés de quem é admirador do "gran caudillo" (BRANDT, 1981, p.54)

O romance é intercalado pela fala de Malinche que também é personagem-narradora, representada ao estilo heroína romântica que fala de um tempo em que seu nome já é sinônimo de La Chingada ${ }^{12}$, como mais tarde a historiografia mostra, mas que se considera, contrariamente, alguém que deu seu corpo gratuitamente, por amor, a Hernán Cortés.

O pai a nomeia Maliche, ao nascer e anos mais tarde Cortés a nomeia Dona Marina, mesmo antes do batismo. A mãe era Chituche, filha de um chefe de aldeia submissa e admiradora dos astecas, estrangeira em Painala e o pai, Taxumal, cacique de Painala. Aprendeu a língua Nahúatl ao Painala cair sob o domínio dos astecas. Como povo conquistado, deviam aprender a língua do conquistador e para isso compraram um escravo que soubesse falá-la. Malinche a aprendeu enquanto ainda criança.

É mencionada a morte de Ahuitzotl e que logo Montezuma se torna o novo tatloani ${ }^{13}$ dos astecas. Pouco antes da coroação de Montezuma, alguns estrangeiros chegaram à costa de Yucatán. Segundo Brandt (1981), Montezuma, quando teve as primeiras notícias dos estrangeiros que chegavam, ficou várias horas consultando as estrelas para ter informações sobre serem os deuses que voltavam. Cabe mencionar que os astecas, principalmente Montezuma acreditavam que Hernán Cortés era o deus Quetzacoátl que retornava do

11 RESTALL,Matthew,2003; LOCKHART,James,1994; GILLESPIE,Susan D.;1989, TOWNSEND Camilla, 2003; BURKHART, Louise, 2001; GRAULICH, Michel, 2001; SMITH, Michael E.,2001; CARRASCO, David,1982, NICHOLSON, HB, 2001; POHL ,John ,2016; CARRASCO, David, 2000; ALDHOUSE-GREEN, Miranda Jane, 2001; TIERNEY, Patrick, 1989. ALTAMIRANO, Ignacio Manuel, 1988; CYPESS, Sandra Messinger,2008; HERNÁNDEZ, Cristina González, 2002; HERNÁNDEZ, Sonia, 2008; JACOB, Jorcy Foerste, 2014; JAGER, Rebecca Kay, 2015; JONES, María Elena Gaborov, 2018; JOSÉ, Maria Emilia Granduque, 2011 e incontáveis outros estudiosos.

12 Para buscar as origens etimológicas do vocábulo "chingar", de seu correlato "chingada", e como quase tudo no México, é preciso remeter-se ao náhuatl. Pode derivar de "xinachtli", semente de hortaliça, ou "xinaxtli", garapa fermentada; vozes cujos derivados são usados no mundo hispânico associados a bebidas alcoólicas, a resíduos ou à borra que fica nos copos, segundo informa Dario Rubio em "Anarquia del Lenguaje en la América Española”, consultado por Octavio Paz. Em conseqüência de ser a chingada uma mãe violentada, aberta pela força, burlada, seu filho será um engendro do rapto e da burla, que não deve ser confundido com o nosso conhecido "filho da puta" brasileiro. Este é o filho de uma mulher que se entregou voluntariamente, o outro é fruto de uma violação, o que não ameniza seu estigma. Dai que, na atualidade, chingar quase sempre leve também implícita uma idéia de fracasso, impotência, burla. Contudo, o termo chingar, tal e qual a própria palavra madre, são polissêmicos na medida em que seu significado dependerá das circunstancias ou da inflexão de voz em que são pronunciadas. Ainda assim, a ideia de abrir, romper ou rachar aparece em quase todos, a final, "rajarse" (rachar-se) é sinônimo de acovardar-se, de fraqueza. Ser um "rajado" é ser um covarde, um maricas, "mulherzinha". MONTANDON, 2007,p. 23-24)

13 líder, chefe, rei. 
oriente, para onde havia partido em tempos imemoriais. E, é válido afirmar que Malinche teria contado esse segredo a Cortés e que este se fez passar pelo deus, diante de Montezuma.

Após o pai ter sido picado por uma serpente, ela herda o título de chefe de Painala, mas a mãe casa-se com o tio e tem um filho a quem desejava que herdasse o título que Malinche recebera. A mãe, com a ajuda do marido forja sua morte colocando em seu lugar o corpo de uma escrava morta e a vende a mercadores, pochtecas. Assim, Malinche vive em Xicalanco, como escrava. Torna-se amiga da primeira esposa e com sua ajuda não é molestada sexualmente, permanecendo virgem.

O proprietário de Malinche teve um contato prévio com os espanhóis e volta com a conclusão de que não eram deuses, como os nativos murmuravam, já que se esperava o retorno de um deus branco que viria do leste, Quetzcoatl. "Eles não são deuses? Os deuses fedem? Eles estão com fome, suam e arrotam? "(BRANDT, 1981, p.47, tradução nossa). ${ }^{14}$ Mas, Malinche, ao encontrar-se com eles, estava convencida de que eram deuses, segundo suas próprias palavras. Assim relata ela: "Nan Chan, aturdido e humilhado, reuniu o séquito que havia acompanhado a cerimônia de entrega dos diálogos que habitam o conquistador na cidade e na terra." (BRANDT, 1981, p.45, tradução nossa). ${ }^{15}$

Jane Lewis Brandt (1981) optou por representar uma Malinche crente que os recémchegados eram enviados dos deuses. Em seguida, após muitas evidências em contrário, (precisavam de intérpretes para se fazer entender, tinham interesse por ouro, em vez de em jade e esmeralda, que seria as pedras preferidas dos deuses, não sabiam onde era o lugar onde morava Montezuma e onde havia ouro em abundância e ignoravam a que distância ficava ou quanto tempo demoraria para chegarem lá), a narradora Malinche continua a convencer-se de que eram deuses. Mesmo com muitas evidências contrárias no interior da narrativa, ela se refere a Cortés como "el gran dios" (BRANDT, 1981, p.48) prejudicando a verossimilhança, a lógica interna do enredo, pois somente há referências a que os estrangeiros não eram deuses e sim humanos. Ela mesma tem várias comprovações durante a narrativa: fato que provoca dúvidas quanto à representação de uma Maliche convencida da presença dos deuses foi quando Cortés aparece em seu cavalo, fazendo uma demonstração deste ser desconhecido aos indígenas foi o pensamento de Malinche: "Pareceu-me claro que eu havia chamado a besta sobrenatural para impressionar Nan Chan." (BRANDT, 1981, p.48, tradução nossa). ${ }^{16}$ Precisaria um deus impressionar um humano com demonstrações de poder? Não bastaria que impusesse sua vontade divina ao humano?

Através deste personagem, Arturo Mandragón, se inserem informações biográficas históricas sobre Hernán Cortéz, a saber: ter abandonado a escola de leis em Salamanca, ter escalado uma parede para entrar no quarto de uma mulher casada até que foi obrigado, devido ao escândalo de ter caído da janela ao ser perseguido, sem roupas pelo marido da dama que chegara repentinamente, a alistar-se em uma expedição que partia para as Índias Ocidentais. Conheceu o governador Velázquez, foi nomeado por ele alcaide de Santiago, ganhou a chefia da expedição para o novo mundo, chefia essa desejada por muitos, incluindo Pánfilo de Narváez.

Arturo Mandragón, personagem totalmente fictício, é apaixonado por Amadís de

\footnotetext{
14 “¿No son dioses? ¿Acaso apestan los dioses? ¿Acaso tienen hambre, y sudan, y regüeldan?” (BRANDT, 1981, p.47).

15 "Nan Chan, aturdido e humiliado, reunió el séquito que havia de acompañarle em la cerimonia de su rendición a los dioses que habían conquistado su ciudad y su tierra” (BRANDT, 1981, p.45).

${ }^{16}$ Me pareció claro que había llamado a la bestia sobrenatural para impressionar a Nan Chan” (BRANDT, 1981, p.48).
}

https://periodicos.unifap.br/index.php/letras Macapá, v. 9, n. 1, $1^{0}$ sem., 2019 
Gaula e El Cid Campeador, e La Celestina, livros pelos quais o personagem histórico Hernán Cortés também era fã, ${ }^{17}$ e atraído pelas lendas das belas amazonas e pela existência de ouro trazido por Grijalva e seus homens das terras do novo mundo, almeja ingressar na expedição de Cortés.

Interessante perceber que os escritores de literatura usam bases históricas para escreverem seus romances e somente a partir dos vácuos deixados nessas bases, usam a imaginação para preenchê-los. Jamais se distanciam dessas bases históricas. Como Malinche é um personagem com múltiplos espaços em brancos, e sobre a qual muito pouco se sabe, as cavidades à espera de que a imaginação dos escritores preencha, são imensas.

Jane Lewis Brandt traz para suas páginas o amor que, se sabe, Hernán Cortés mantinha por personagens literários, cavaleiros medievais como Rolando e El Cid: "Sempre me imaginei Alejandro, Roldán e El Cid montando um cavalo." (LEWIS BRANDT, 1981, p.61, tradução nossa)..$^{18}$

$\mathrm{Na}$ segunda carta de relación, Cortés fala do encontro com os povos submissos a Montezuma, e ao perguntar se são súditos do tatloani, os caciques perguntavam admirados se havia alguém no mundo que não era. ${ }^{19}$ Isso está descrito, quase que literalmente, no romance de Brandt: “Alguém não é?” (BRANDT, 1981, p. 138, tradução nossa) 20

Quanto à participação de Malinche nos acontecimentos de Cholula, Arturo Mandragón, o narrador de Malinche de Lewis, descreve que os tlaxcaltecas se tornaram súditos de Carlos V, o que logo aconteceu, como as fontes primárias descrevem. Os espanhóis acamparam fora da cidade de Cholula, onde receberam cordial boas vindas e ofereceram para que os espanhóis se hospedassem com eles, mas proibiram os indígenas de Tlaxcala ${ }^{21} \mathrm{de}$ entrarem na cidade. Outra nação indígena que os acompanhavam, os nativos de Zempoalla foram também convidados a entrarem na cidade; somente os tlaxcaltecas esperariam fora dos muros da cidade até que todos se reunissem novamente para continuar a marcha até Tenochtitlán. Os espanhóis foram recebidos com música e os nobres traziam suas esposas para conhecê-lo e um banquete foi preparado para eles. Durante

o banquete, uma mulher da nobreza se ajoelhou ao lado de Malinche e conversou longamente com ela. Logo, Malinche foi vista conversando com a nobre de Cholula e depois disso, dirigiu-se aos aposentos onde dormia com Cortés e foi interceptada pelo narrador, Mandragón, que a advertiu sobre manter relações de amizade com a mulher da nobreza, pois essa poderia arrancar-lhe algum segredo. Malinche retruca que mais provavelmente seria ela quem arrancaria segredos da mulher e que a mulher apenas queria que ela casasse com seu filho e que a senhora a tinha convidado a morar com ela, pois de outra maneira teria que compartilhar com a mesma sorte que os espanhóis que mantinham Malinche prisioneira, teriam que enfrentar. Assim, Malinche planeja descobrir qual seria a sorte futura dos espanhóis. Para fazer a mulher acreditar que realmente era uma prisioneira, Malinche

\footnotetext{
${ }^{17} \mathrm{Nada}$ a estranhar que este espírito de cavalaria encontrasse guarida nas descrições da conquista deixadas por cronistas espanhóis, e que personagens ficcionais inspirassem a ação dos desbravadores das novas terras anexadas aos domínios dos reis católicos. O relato de Bernal Diaz de Castillo, a Historia Verdadera de la Conquista de Nueva España, apresenta-nos correlações interessantes entre o conquistador Hernan Cortez e o herói da Reconquista hispânica, o Cid, ou o personagem Rolando das canções de gesta. (MACEDO, 2008, p. 12).

18 "Siempre me imaginaba a Alejandro, Roldán y el Cid, a lomos de um corcel." (BRANDT,1981, p. 61).

${ }^{19}$ After I had spoken to him on behalf of Your Majesty and of the reason for my coming to these parts, I asked him if he was a vassal of Mutezuma or owed some other allegiance. And he showed surprise at my question, and asked who was not a vassal of Mutezuma, meaning that here he is king of the whole world. (CORTÉS, 1986, p. 141).

20 “'Acaso alguién no lo és?” (BRANDT, 1981, p. 138).

${ }^{21}$ Historicamente inimigos do povo de Cholula e dos astecas.
} 
se faz acompanhar por Mandragón, que age como se fosse um carcereiro e vai ao encontro da nobre cholulana para desvendar-lhe o segredo. A mulher lhe conta em segredo que havia um plano de atacar os espanhóis. Malinche pede que a mulher vá com ela até onde vive com os espanhóis para que a ajude a empacotar roupas e ali, chama Cortés e vários espanhóis que prendem a dama de Cholula. A indígena confessa, aterrorizada que Montezuma havia subornado os nobres de Cholula para que aniquilassem os espanhóis quando esses saíssem da cidade, com a ajuda de astecas que esperariam do lado de fora da cidade e depois chega perto de Malinche e a reprova por estar do lado dos espanhóis, sendo indígena. Malinche responde que o motivo era que havia se tornado cristã. (BRANDT, 1981, pp.152-157)

Vemos que Jane Lewis Brandt (1981) no que se refere ao massacre de Cholula, segue as indicações de Cortés que menciona em sua segunda carta de relação que Malinche teria ouvido sobre uma armadilha que estava sendo preparada aos espanhóis pelos habitantes de Cholua. Mais exatamente e com detalhes, a indicação de Bernal Díaz Del Castillo: Malinche teria descoberto o complô, contou o plano a Cortés que comanda o massacre.

Malinche, segundo Brandt, assumiu totalmente a ideologia espanhola, chegando a referir-se aos astecas como inimigos, malditos, que regavam seus terraços, chinampas, com sangue espanhol, especialmente no que se chamou de Noite triste. (BRANDT, 1981, p. 300). Tal como a historiografia, Brandt (1981) se referiu ao episódio dos espanhóis sendo expulsos da capital mexicana pelos astecas de Noite Triste, Notche Triste. ${ }^{22}$.

O invadido foi chamado de inimigo pelo invasor; somente uma total inversão ideológica de Malinche, uma completa simbiose com os espanhóis faria com que visse os astecas como os inimigos. A explicação para o ódio aos conquistados está inserida no próprio romance. Segundo a escritura de Brandt (1981): “Odiamos a quem prejudicamos." (BRANDT, 1981, p. 330)

Segundo a imaginação de Brandt, talvez irônica, Cortés guardava ideais humanitários em relação aos povos conquistados, pelos quais desejava guiar-se, bem como também os guardava sua tradutora. Diz-nos Malinche: "Minha própria elevação de categoria social não significava nada para mim, o que importava era que Cortés finalmente tinha a autoridade necessária para realizar seus ideais humanitários em relação aos povos conquistados" (BRANDT, 1981, p. 328, tradução nossa). ${ }^{23}$ Brandt representa uma Malinche que crê que as intenções do ambicioso conquistador espanhol eram totalmente cristãs: "Você não entende Cortés. O que ele quer, acima de tudo, é cristianizar os nativos da Nova Espanha." (BRANDT, 1981, p. 329, tradução nossa). ${ }^{24}$

A escritora escolheu por nos mostrar, ainda, uma Malinche certa de que o espanhol dava a ela elevada importância e que foi surpreendida quando esse acolheu Catalina, a esposa espanhola, (fatos comprovados historicamente) que vinha para a Nova Espanha:

Vejo que você tem que explicar algumas coisas. Você é minha amante e desfruta do meu carinho e proteção. Mas Catalina é minha esposa legal e tem direito a meu respeito, nestas horas ouviu falar de você. Nego-me a discutir com ela sobre você. E não quero discutir com você sobre ela. [...] Você está tentando me fazer prometer de que não vou dormir com ela? Com minha esposa legítima? O que quer

\footnotetext{
22 Os ataques astecas não cessaram e os espanhóis resolveram fugir à noite, até que foram descobertos e começou outra grande batalha onde metade do exército de Cortez é morto, seria a Notche Triste. (MORAIS, 2006, p.9).

23 "Mi popria elevación de categoria social nada significaba para mí, lo que importaba era que Cortés tenia al fin la autoridade necessária para realizar sus ideales humanitários em lo tocante a los pueblos conquistados." (BRANDT, 1981, p. 328).

24 "No comprendéis a Cortés. Lo que éste quiera, por encima de todo, es cristianizar a los indígenas de Nieva espana." (BRANDT, 1981, p. 329).
} 
Assim, Malinche percebe o que representava para Hernán Cortés: "Ela era sua esposa espanhola, eu era sua amante índia.” (BRANDT, 1981, p. 338). (BRANDT, 1981, p. 338, tradução nossa). ${ }^{26}$

E, no romance de Brandt, a personagem casa-se, seguindo os fatos históricos, com Juan Jaramillo: "Que questão do seu futuro. Eu pensei um pouco sobre isso. Não pretendo que você viva sozinha, como uma mulher abandonada. Você precisa de um marido. Proponho a Don Juan Jaramillo.” (BRANDT, 1981, p. 373, tradução nossa). ${ }^{27}$

Quando a esse detalhe se percebe que a tese da acadêmica Camilla Townsend (2006) de que Malinche teria escolhido casar-se com um espanhol menos poderoso,que poderia achar atraente um matrimônio com uma indígena influente, vem ao encontro da criação de Brandt (1981). Segundo a letrada, se o espanhol tivesse certa influência, poderia proteger Malinche e seus interesses e ela poderia ter barganhado com Cortés por esse casamento. Townsend diz que documentos do século dezesseis contêm amplas evidências de que uma indígena nobre podia usar maridos espanhóis para ganhar batalhas legais de terra e outros bens. (TOWNSEND, 2006, p. 130) Coube a Malinche aceitar o matrimônio, bem como também terras e fazendas, referência à La Hacienda Galindo, que Malinche recebeu no ano de 1524 e que se situa perto de San Juan Del Río 28.

Como presente de casamento, pretendo conceder-lhe uma esplêndida concessão de terras. E eu também lhe darei, em um grau muito maior. Quero que você tenha uma fazenda que abranja sua pequena cidade de Paynala e muitas ligas ao seu redor. [...] Também desejo lhe dar algumas joias. (BRANDT, 1981, p. 373 , tradução nossa). ${ }^{29}$

Brandt recusa-se a falar de que Malinche tenha recebido seus escravos, mas certamente eles seriam necessários para o trabalho da terra em um sistema de encomendas e não podemos esquecer que, na lâmina número sete do Lienzo de Tlaxcala, Malinche recebe escravas. (SEGER, 2014, p. 149)

O romance termina com uma Malinche que fica vivendo entre os seus, como uma grande senhora que reconhecia que Cortés era odiado por milhões de indígenas e que certamente deviam odiá-la também, pois a chamavam de La Chingada e rameira, epíteto que, como já esclarecemos, adquiriu somente durante a Revolução Mexicana. Diz ela:

\footnotetext{
${ }^{25}$ _ Ya veo que tendré que explicarte algunas cosas. Eres mi amante y gozas de mi afeto y mi protección. Pero Catalina es mi esposa legal y teine derecho a mi respeto. Sin duda, a estas horas le habrán hablado de ti. Me negré a discutir com ella acerca de ti. Y no deseo discutir contigo acerca de ella. [...] ¿ ‘Tratas de arrancarme la promessa de que no dormirá com ella? ¿Com mi esposa legítima? Lo que haga com ella no debe importarte.” (BRANDT, 1981, pp. 328329).

26 "Ella era su esposa española, yo era su amante índia." (BRANDT, 1981, p. 338).

${ }^{27}$ Que ala cuestión de tu futuro. He pensado um poco en esto. No pretendo que vivas sola, como uma mujer abandonada. Necessitas um marido. Propongo a don Juan Jaramillo.” (BRANDT, 1981, p. 373).

${ }^{28}$ Informações contidas em ARIAS RAMÍREZ, Virgilio Adrián. Malinche La abuela zoque. México: CONECULTA, 2016, pp. 59-60.

${ }^{29}$ Como regalo de boda, pienso otorgarle uma espléndida concesión de tierras. Y también te dotaré a ti, em grado mucho mayor. Quiero que tengas uma hacienda que abarque tu pequena ciudad de Paynal y muchas léguas a su alredor.[...] Tembién deseo regalarte unas cuantas joyas.” (BRANDT, 1981, p. 373).
} 
Mas as prostitutas vendem seu corpo, e eu dei o meu. Outros me chamam de traidor. Eles também são truques. Os astecas nunca foram meu povo, mas meus opressores e Cortés se lançou contra os astecas, lutou com eles e os derrotou. Então, eu não traí ninguém. (BRANDT, 1981, p. 376, tradução nossa). 30

Aqui o pensamento de Brandt (1981) encontra-se com o historiador Arias Ramírez (2016) que recorda que o império dos astecas durou 196 anos, que eles submetiam muitos outros povos que desejavam libertar-se dessa opressão, que não existia tal conceito, pátria e que Malinche não devia fidelidade ou respeito aos astecas. (ARIAS RAMÍREZ, 2016, p. 66).

\section{La Princesa Azteca de Colin Falconer (1992)}

No romance La Princesa Azteca de Colin Falconer (1992); Malinche é projetada como uma princesa asteca, como preferiu descrever Bernal Díaz, que acredita que Hernán Cortés seja realmente a encarnação do deus Quetzalcoatl que retorna e, o fato de crer, direciona suas ações.

Falconer recria a infância de Malinche, temida pela mãe que pressentia nela uma desgraça para seu povo e que tenta afogá-la num lago, ainda criança. Falconer descreve uma Malinche que foi escrava e usada sexualmente pelos homens olmecas que tinham sido seus donos a quem servia no que se chamava "casa dos homens".

Maliche aconselha Cortés a matar Cuauhtémoc, águia caída, o último dos tatloanis astecas, a quem o espanhol mantinha prisioneiro, por muitos anos: - Mas me forcei a dizer o que tinha que ser dito: “- Meu senhor, hoje à noite você deve matar o Príncipe da Águia Caída. Enquanto ele viver, você e todos os espanhóis estarão em perigo.” (FALCONER, 1992, p.139). ${ }^{31}$ Malinche refere-se à morte do tatloani como se fosse um triunfo seu, completamente submersa na ideologia espanhola, como se estivesse ela mesma numa guerra contra os indígenas e que finalmente fosse a conquistadora que triunfava. Também, por considerar-se católica, vê a batalha que se travou como tendo sido uma batalha entre deuses e vencia o deus cristão sobre todos os deuses do panteão asteca: "¿Qué importaba si era inocente o culpable? ¿Quién lo sabía a quién importaba? Murió porque um dios se había vuelto loco y exigia sacrifício.” (FALCONER, 1992, p. 141) Essa é uma visão muito espanhola, conforme escreveram nas suas cartas e crônicas.

Falconer aproxima, brevemente, La Malinche de La Llorona descrita nas crônicas de Sahágun como a um dos sinais proféticos da chegada dos espanhóis. (SAHAGUN, 2009, p. 403)

Falconer faz referência ao Lienzoo de Tlaxcala ao relembrar os tlaxcaltecas como mentirosos, "suas únicas canções são os gritos de guerra que mencionam suas vitórias "(FALCONER, 1992, p.225, tradução nossa) 32

Seguindo o que nos diz a História, o escritor mostra um Cortés que têm como livro de cabeceira El Cid, o grande guerreiro a quem os soldados cantavam baladas. Ao ouvir que Malinche tinha ouvido os espanhóis falarem sobre o herói espanhol, pergunta a ela onde ouviu as histórias. Ela responde que somente dos soldados espanhóis. Cortés, então,

\footnotetext{
${ }^{30}$ Pero las rameras venden su cuerpo, y yo die 1 mío. Otros me llaman traidora. También son unos embusteiros. Los azteccas nunca fueron mi Pueblo, sino sus opressores, y cortés se lanzó contra los astecas y luchó com ellos e les venció. Así, pues, yo no traicioné a nadie. (BRANDT, 1981, p. 376).

31 "Pero me forcé a mí miesma a decír lo que tenía a ser dicho: - mi señor, esta noche debes matar al Príncipe Águila Caída. Mientras él viva, tú y todos los espanõles estáis em peligro.” (FALCONER, 1992, p.139)

32 "sus únicas canciones son gritos de batalla que mentan sus victorias." (FALCONER, 1992, p. 225).
} 
expressa seu desejo de que o mundo todo, inclusive os indígenas, tivessem ouvido as histórias a respeito dele e diz que "todos os meninos querem se tornar homens e ser como El Cid” (FALCONER, 1992, p. 226). ${ }^{33}$ Há, ainda, referência a Amadis de Gaula: Malinche se perguntava se o aventureiro Hernán Cortés se assemelharia ao personagem e se o sonho do aventureiro era descobrir novas terras e reinos maravilhosos como nas lendas de cavalaria. (FALCONER, 1992, p. 237)

Quanto ao casamento de Maliche com Juan Jaramillo, o romance nos diz que este é arranjado por Cortés: "Cortés tinha arranjado meu casamento com Don Juan Xaramillo, um capitão da marinha espanhola que poderia me dar respeitabilidade" (FALCONER, 1992, p.242, tradução nossa). ${ }^{34}$

O escritor nos apresenta uma Malinche que sabia que a chamavam de traidora e de que essa era sua fama na época: "O garoto olhou para mim sem falar. Aos seus olhos, li as histórias [...] de uma prostituta chamada La Malinche, um monstro cheio de traição. Eu era para ele essas duas mulheres: nunca seria outra coisa." (FALCONER, 1992, p. 244). ${ }^{35}$

De acordo com os documentos, essa fama de culpada da destruição dos indígenas somente viria a surgir muito mais tarde, com os acadêmicos nacionalistas, ao buscarem uma identidade que mais se identificassem e com os trabalhos de Octavio Paz. ${ }^{36}$

Falconer descreve uma Malinche amiga de um Bernal Díaz, ardoroso fã de histórias e que, quando ela encontra-se com a mãe e o meio-irmão, na viagem a Honduras, ele fica na expectativa de vê-la agir como uma bondosa princesa de seus contos medievais. Muitos historiadores e acadêmicos perceberam que Bernal Díaz escreveu seu livro pretendendo contar a história verdadeira das campanhas que fez com Hernán Cortés na Nova Espanha, mas que acabou fazendo uma história romanceada ao estilo das histórias de cavalaria que tanto gostava. Falconer (1992), com certeza, leu Bernal Díaz, percebeu e pesquisou isso antes de escrever seu livro e nos apresenta um personagem, Bernal Díaz, esperando que o encontro se desse seguindo os parâmetros medievais:

Então ouvi aplausos e aplausos e, olhando em volta, vi que uma dúzia de soldados haviam se reunido. Murillo, Bernal Díaz e López estavam perto de mim, sorrindo para mim. Eles haviam conhecido as boas novas da sobrevivência da minha família e vieram se juntar a mim para agradecer por isso. (FALCONER, 1992, p.244, tradução nossa). ${ }^{37}$

O autor de História Verídica não esperaria outro tipo de encontro: "Esse foi o material de seus romances: a mãe do mal, a princesa vendida a bandidos. Agora eles estavam esperando pela última cena: perdão e reconciliação. Eu não o desapontaria. "(FALCONER, 1992, p.244, tradução nossa) ${ }^{38}$ A sequência relatada acima se dá exatamente como a descrição de $A$ verdadeira história da conquista da Nova Espanha. Malinche dá joias aos dois, à mãe e ao irmão, que parecem temerosos de recebê-las e ela sussurra para a mãe, sem que Bernal

\footnotetext{
33 “todos los muchachos desean hacerse hombres y ser como el Cid." (FALCONER, 1992, p. 226).

34 “Cortés había arreglado mi matrimonio com don JuanXaramillo, um capitán de la mariña española que podia darme respetabilidad." (FALCONER, 1992, p. 242).

${ }^{35} \mathrm{El}$ muchacho me miraba sin hablar. Em su ojos leí las historias de la malvada hermana que afortunadamente murió. Y otras histórias no de su hermana, sino de uma puta llamada La Malinche, um monstruo lleno de traición. Yo era para él estas dos mujeres: nunca sería outra cosa. (FALCONER, 1992, p. 244)

36 Octavio Paz (1914-1998), autor de El laberinto de la soledad, Primera edición (Cuadernos Americanos), 1947.

37 "Entonces oí aplausos y vítores y, al mirar al mi alrededor, vi que se habían reunido uma docena de soldados. Murillo, Bernal Díaz y López estaban cerca de mí, sonriéndome. Habían sabido las buenas nuevas de la supervivência de mi família y habíanvenido a reunirse conmigo para dar gracias por ello.” (FALCONER, 1992, p. 244)

38 "Eso era el matéria de sus romances: la madre malvada, la princesa vendida aos bandidos. Ahora esperaban la última escena: pedón y reconciliación. No les decepcionaria.” (FALCONER, 1992, p. 244).
} 
ouça, que se tem coragem e não quer receber o presente, que recuse. Isso se dá sem que os espectadores percebam e quando o encontro termina Malinche conclui que os que observavam estavam comovidos e que a história romântica tinha acabado como os observadores esperavam.

O romance La Princesa Azteca de Colin Falconer (1992) vem a dizer que Malinche não somente acreditava que Cortés era um deus, como diz que ela, sem a intervenção de Cortés, decide dizer isso aos mensageiros de Montezuma. Quando os enviados a chamam de traidora de sua própria gente e aconselham a eles que partam antes que percam a vida quando chegarem à Tenochtitlán, ela decide dizer que vinha com um deus e que não temia nada. Quando Aguilar pergunta o que tinha dito, ela respondeu que tinha usado de um subterfúgio religioso. Então, segundo Falconer (1992), Malinche teria sido responsável pela confusão de Montezuma sobre a verdadeira identidade dos homens que chegavam, se eram deuses ou humanos. (FALCONER, 1992, p. 187)

Falconer decide nos apresentar uma Malinche que acreditava totalmente que Cortéz não queria o ouro dos astecas, e que ao pegá-lo somente cedia ao desejo dos outros companheiros espanhóis, pois ele não cometia atos torpes. Essa ganância dos outros espanhóis deveria provocar vergonha em Cortés tanto que ele teve que explicar, usando de ironia, que os espanhóis sofriam de uma enfermidade cuja única cura vinha pela posse de ouro. (FALCONER, 1992, pp. 181-182) Noz diz essa Malinche crédula: "Ninguém entendia melhor os sintomas dolorosos e a fatalidade da ganância do que ele. Ele estava completamente cercado por homens que morreram por causa dela. "(FALCONER, 1992, p.182, tradução nossa). ${ }^{39}$

Segundo ela, Hernán Cortés era totalmente voltado a ideais nobres.

Quanto ao massacre acontecido em Cholula, Falconer o representa de acordo com a historiografia estudada. A cidade de Cholula era totalmente devota do deus Serpente de Plumas, Quetzacoátl. Diz-nos Malinche que esse povo não poderia ter dúvidas de que Cortés era o deus que retornava: "Você poderia negar a divindade de Cortes? Ele havia chegado, exatamente, como as profecias haviam anunciado. Negá-lo era como negar que dois e dois eram quatro. Era algo contra toda razão." (FALCONER, 1992, p.291, tradução nossa). ${ }^{40}$ Conforme Bernal Diáz, Cortés e seu biográfo Gómara, é descrita a conversa moradora de Cholula, que a avisa que poderia morrer se permanecesse com os estrangeiros que morreriam em Cholula. A nobre de Cholula estaria interessada nas riquezas de Malinche, por isso queria que fosse morar com ela e que casasse com seu segundo filho, segundo opinião descrita em Bernal Díaz. Malinche, assim que se vê só, conta a Cortés o acontecido: "Yo corrí a donde estaba Cortés y le conté toda la historia.” (FALCONER, 1992, p.295, tradução nossa). ${ }^{41}$

Malinche deu sua opinião a Cortés para que o massacre começasse:

Mi señor estaba preguntándome em silencio y yo lo asentí com um gesto, rogándole que atacara ahora, que pusiera fin a este miedo.

El gritó:

\footnotetext{
39 "Nadie comprendía los penosos sintomas y fatalidade final de la codicia mejor que él. Estava completamente rodeado de hombres que morían a causa de ella." (FALCONER, 1992, p.182).

40 "¿Podían negar la divindade de Cortés? Él había llegado, exatamente, tal como habían anunciado las profecias. Negarle a él era como negar que dos y dos eran cuatro. Era algo que iba contra toda razón.” (FALCONER, 1992, p.291).

41 "Corri para onde Cortés estava e contei a ele toda a história." (FALCONER, 1992, p.295).
} 
_ ¡Debéis morir! (FALCONER, 1992, p.298) 42

A descrição do massacre não é muito diferente da segunda carta de Hernán Cortés:

Uma índia que trazia comigo como intérprete soube por outra nativa que eles haviam retirado todas as mulheres e crianças da cidade e que pretendiam matar todos nós. [...] Chamei alguns senhores da cidade, dizendo que queria falar-lhes, e tranquei-os em uma sala com o aviso aos nossos para que quando ouvissem o tiro de escopeta caíssem sobre a maior quantidade de índios possível. e assim foi feito. Em duas horas matamos mais e três mil índios e prendemos na sala todos os chefes. (CORTEZ, 2007, p. 47).

Malinche é concebida como participante ativa no acontecimento e a isso, principalmente, se deve sua fama posterior de traidora dos seus. Como se percebe, Falconer prendese às fontes primárias para apresentar o massacre de Cholula.

\section{Conclusão}

Aqui se pode compreender que esses escritores do século XX se pautaram pelas Cartas de relación, principalmente por Bernal Díaz para compor sua personagem Malinche, sem esquecer as profecias descritas por Sahágun, que, alguns dizem, se propagavam entre os povos autóctones, antes da chegada dos espanhóis. Contribuem para a representação da personagem literária, os estudos historiográficos feitos a posteriori. A acusação de traidora pesa enormemente nas criações literárias.

\section{Bibliografia}

ARIAS RAMÍREZ, Virgilio Adrián. Malinche La abuela zoque. México: CONECULTA, 2016.

BRANDT, Jane Lewis. Malinche. Barcelona: Plaza e Janés, S.A. 1981.

CORTÉS, Hernán. Letters from Mexico. Edited and translated by Anthony Pagden. Introduction by J. H. Elliott. New Haven, CT: Yale University Press, 1986.

DEL CASTILLO, Bernal Díaz. The True History of the Conquest of New Spain (História Verdadera de La conquista de la Nueva España) Translated, with an Introduction and Notes, by Janet Burke and Ted Humphrey. Indianapolis/Cambridge: Hackett Publishing Company, Inc., 2012.

FALCONER, Colin. La Princesa Azteca. México: Martínez Roca, 1992.

GÓMARA, Francisco Lopez. De La conquista de México. Barcelona: Linkgua ediciones S.L. 2009.

GIACOMOLLI. Dóris Helena Soares da Silva. Capitão Rodrigo Cambará atravessa o portal - entre literatura e história. Revista Arredia, Dourados, MS, Editora UFGD, v.3, n.4: 30-39 jan./jul. 2014. Disponível no link: http://ojs.ufgd.edu.br/index.php/arredia/article/view/2859. Acesso em 29.08.2019.

MACEDO, José Rivair. Mouros e cristãos: a ritualização da conquista no velho e no Novo Mundo. Bulletin du centre d'études médiévales d'Auxerre. BUCEMA, Hors-série

\footnotetext{
${ }^{42} \mathrm{Meu}$ senhor estava me pedindo em silêncio e assenti com seu gesto, implorando para que ele atacasse agora, para acabar com esse medo.

O grito:

_Devem morrer! (FALCONER, 1992, p.298)
} 
$\mathrm{n}^{\circ} 2$ | 2008. Disponível em: https://journals.openedition.org/cem/8632.

MAES, Hélène. La Malinche descifrada a través de la carta 'privada' - Análisis comparativo de las novelas epistolares Amor y Conquista (1999) de Marisol Martín del Campo y La verdadera historia de Malinche (2009) de Fanny del Río. 2013. Dissertação de mestrado. Disponível no link: https://lib.ugent.be/fulltxt/RUG01/002/060/361/RUG01002060361_2013_0001_AC.pdf. Acesso em 12.07.2019.

MONTANDON, Rosa Maria Spinoso de. La Llorona. Mito e poder no México. Niterói, 2007. Disponível no link: http://www.historia.uff.br/stricto/teses/Tese 2007_MONTANDON_Rosa_Maria_Spinoso-S.pdf.

MORAIS, Isadora Machado B. de. A história vista de baixo: a visão asteca da conquista espanhola. Ameríndia, volume 2, número 2/2006.

PASSUTH, Laszlo. O Deus da Chuva Chora Sobre o México. Belo Horizonte: Itatiaia,1963.

PAZ, Octavio. Los hijos de la Malinche. Cap. 4 In: El laberinto de la Soledad. Mexico City: Cuadernos Americanos, 1947.

SAHAGÚN, Fray Bernardino de. Historia general de las cosas de la Nueva España 02 vols. Barcelona: Linkgua S.L., 2009.

SEGER, Magda Fabiane. La Malinche, D. Marina: a "lengua" de Cortés segundo o “Lienzo de Tlaxcala" São Leopoldo, 2014. Disponível no link: http://www.repositorio.jesuita.org.br/handle/UNISINOS/4253. 